\title{
THE IMPACT OF MINIMUM WAGES FOR DOMESTIC WORKERS IN Bloemfontein, South Africa
}

Authors:

Phillip F. Blaauw ${ }^{1}$

Louis J. Bothma ${ }^{1}$

\section{Affiliations:}

${ }^{1}$ Department of Economics

\& Econometrics, University

of Johannesburg,

South Africa

Correspondence to:

Phillip Blaauw

email:

pfblaauw@uj.ac.za

\section{Postal address:}

Department of Economics \& Econometrics, University of Johannesburg, PO Box 524, Auckland Park 2006,

South Africa

\section{Keywords:}

regulation; employment conditions; structural changes; compliance; employment effects

\section{Dates:}

Recieved: 11 May 2009

Accepted: 08 Sept. 2009

Published: 12 Mar. 2010

How to cite this article: Blaauw, P.F., \& Bothma, L.J. (2010). The impact of minimum wages for domestic workers in Bloemfontein, South Africa. SA Journal of Human Resource Management/ SA Tydskrif vir Menslikehulpbronbestuur, 8(1), Art. \#216, 7 pages. DOI: 10.4102/sajhrm.v8i1.216

\section{This article is available} at: http:/ /www.sajhrm.co.za

(C) 2010. The Authors. Licensee: OpenJournals Publishing. This work is licensed under the

Creative Commons

Attribution License.

\begin{abstract}
Orientation: The number of domestic workers in South Africa has decreased in the last decade, seemingly corresponding with efforts by government to increase regulation.
\end{abstract}

Research purpose: The purpose of this study was to investigate possible structural changes in this labour market over the last decade, as well as the possible employment effects of the latest minimum wage provisions.

Motivation for the study: Previous studies on the topic were carried out either prior to, or just after, the implementation of the minimum wage legislation for domestic workers. Now, five years after implementation, the conclusions and predictions of these studies need to be evaluated.

Research design, approach and method: The study utilised a repeat survey in the suburb of Langenhoven Park in Bloemfontein, where two previous microstudies had been conducted. Structural interviews were conducted with a sample of 132 respondents and the data analysed.

Main findings: There are now fewer domestic workers working for more employers, than there were ten years ago. In contrast to predictions from the literature, these changes mostly occurred before the implementation of the legislation. Real wages and legislative compliance improved for those who remained employed.

Practical implications: The task of balancing the improvement of the lives of domestic workers and the possible adverse consequences of the legislation, in the form of job losses, remains as daunting as it was ten years ago.

Contribution: Literature predicts changes in the market for domestic workers to be long term. This study shows that most changes took place before the implementation of the legislation as employers decided on their course of action.

\section{INTRODUCTION}

Statistics show that domestic workers, the vast majority of whom are women, remain a crucial part of the South African economy. The number of domestic workers in South Africa has decreased in the last decade since September 2000 (Wilson, 2006). In March 2006, domestic work accounted for 850000 jobs $(6.8 \%)$. This represents a decrease of 3.9 per cent from the level of March 2003, when there were 884 000 domestic workers (Statistics South Africa, 2006a). These declining numbers seem to correspond with efforts by government to increase regulation in this sector through the introduction of minimum wages for domestic workers and compulsory Unemployment Insurance Fund (UIF) deductions.

\section{Background to the study}

In May 1999, the Minister of Labour announced his intention to legislate minimum wages for domestic workers in South Africa. An investigation by the Department of Labour followed the announcement in 1999 of proposed minimum wage legislation for domestic workers in South Africa. As a result, a report entitled Investigation into minimum wages and conditions of employment of domestic workers was released July 2001. It revealed significant wage differentials between urban and rural domestic workers. The wages of domestic workers in rural areas were consistently lower than those of their urban counterparts, with median monthly wages of R409.00 and R588.00 respectively in 2000. Differences also occurred at a provincial level. Domestic workers earned the highest wages in Gauteng and the lowest in the Free State in 2000. As a result, three minimum hourly wages were recommended in accordance with the size of the specific municipal council areas. The suggested wages were R3.07 in Area A (where the urban population comprised 61 per cent or more of the total population), R2.65 in Area B (where the urban population represents 41 to 60 per cent of the total), and R2.05 in Area C, where the urban population is less than 40 per cent (Van den Berg, 2001, p. 2).

In August 2002, the minister announced the Sectoral Determination 7: Domestic Worker Sector, following the recommendations of the above report (Department of Labour, 2002). However, the determination deviated in several respects from the recommendations of the original investigation report, which stipulated that differentiated hourly minimum wages were to be paid, depending not only on the municipal council area in which the domestic worker is employed, but also on the number of hours worked per week. Only two areas, A and B (instead of three as suggested in the original report), were identified in the determination. Area A included all cities and certain towns. The minimum hourly wage for domestic workers who worked more than 27 hours per week was R4.10. The corresponding figure for those working 27 hours or less was R4.51 (Department of Labour, 2002). Area B was loosely described as 'the rest of South Africa' (Bothma \& Campher, 2003, p. 191). Lower minimum hourly wages were prescribed here. Domestic workers who work for 27 or fewer ordinary hours per week had to be paid R3.66; those who work more than 27 ordinary hours per week the minimum hourly rate was R3.33 (Department of Labour, 2002). In addition, the minister prescribed annual wage increases of eight per cent instead of the six per cent that had been recommended in the report (Bothma \& Campher, 2003, p. 191). 
The above minima were set above the median hourly wages that were prevalent at that time. This implied that the intervention by government was a significant one (Hertz, 2004, p. 1). What needed to be established, however, was how these wage levels and proposed increases affected the employment and non-wage conditions of service for domestic workers.

\section{Literature review}

Where minimum wages are under discussion, the impact on employment levels is always a key issue (Van den Berg, 2001 p. 2). In spite of this, academic literature on the topic is fairly limited (Department of Labour, 1996, p. 65). Research which summarises the current state of knowledge in this field includes studies by Davidson and Grossett (1995), Hertz (2004), Bothma and Jordaan (1998), Van den Berg (2001) and Bothma and Campher (2003).

In a microstudy conducted in Bloemfontein before the implementation of the minimum wages, Bothma and Jordaan (1998) predicted that a minimum wage of more than R600.00 per month would lead to a decrease in the demand for full-time domestic workers and that further increases in minimum wages could aggravate the situation. They cautioned that the effect of the legislation would possibly only become clear in the long run (Bothma \& Jordaan, 1998, p. 496).

Hertz (2004) suggests that the real wages of domestic workers increased and the non-wage terms of employment improved as a result of the implemented regulations. Furthermore, Hertz (2004) found that, on a macro-level, regulations did appear to have raised the wages of domestic workers in South Africa, but the decrease in employment of domestic workers could not significantly be linked to these regulations. Average nominal hourly wages in September 2003 were 23 per cent higher than those of September 2002. The nominal wage increase for workers in other occupations with similar demographics was less than five per cent. This finding was supported by econometric evidence that the wage increases for domestic workers were the result of the regulations, because the largest wage increases were seen in places where the greatest number of workers initially earned less than the minimum wage (ibid., 2004, p. 1). The minimum hourly wage for Bloemfontein at the time of the study was R5.11 for domestic workers working more than 27 hours per week and R6.04 for those working less than that. This wage was the same as for other urban areas in South Africa (Department of Labour, 2006a, p.1).

The regulations also seemed to affect some of the nonwage conditions of employment, such as having a written service contract and being registered for UIF. These are legal requirements as per the Sectoral Determination 7: Domestic Worker Sector (Department of Labour, 2002). According to Hertz (2004), the proportion of domestic workers who reported having a written contract of employment rose from a mere seven per cent in February 2002 to 25 per cent in September 2003. The number of domestic workers who reported UIF deductions rose from three to 25 per cent over the same period. Domestic worker employment levels also appeared to have fallen by about three per cent, but this decrease was not statistically significant. Hertz did not find econometric support for the proposition that it was causally connected to the wage changes (ibid., 2004, p. 1). He further reported a statistically significant reduction in the hours of work among the employed, which fell by about four per cent for domestic workers. For workers in other occupations the figure remained constant.

Bothma and Jordaan (1998) and Bothma and Campher (2003) conducted successive microstudies in the same suburb (Langenhoven Park) in Bloemfontein. In their 1997 study, Bothma and Jordaan (1998, p. 493) postulated that an increase in the number of part-time domestic workers would be a distinct possibility should a minimum wage for domestic workers of
R600.00 per month be put in place. As many as 23.2 per cent of the respondents indicated that they would dismiss their fulltime domestic worker should this increase be implemented. Bothma and Jordaan (1998, pp. 495-496) recommended that minimum wages for domestic workers should be regressive, with higher wages instituted for part-time workers, rather than for those who are employed full-time.

Van den Berg (2001), as well as Bothma and Campher (2003), found that the demand for domestic workers was decreasing and that minimum wages could further suppress the demand. Importantly, Bothma and Campher's microstudy of Langenhoven Park indicated that the wages of domestic workers varied not only between areas, but also within areas. Domestic workers who worked in houses earned more than those who worked in townhouses. This may be attributed partly to the scope of the tasks performed and partly to the income differentials of employers. The fact that the workload in houses seems to be higher than in townhouses and that houses generally have more occupants than townhouses, cause a reciprocal influence. As a result, domestic workers work longer average hours in the former (Bothma \& Campher, 2003, p. 204). Bothma and Campher (2003, p. 204) state that should job losses occur, rural and full-time domestic workers will be those most affected. Their finding seems to give merit to Cosatu's 2001 proposal that minimum wages should be set not according to geographical differentials, but according to work performed (Cosatu, 2001, p. 4)

Overall, the literature shows that both the nominal and the real wages of domestic workers increased after the implementation of minimum wage legislation in 2002. The micro- and macrostudies show that there was also an improvement in some of the nonwage conditions of employment in this labour market. The various studies all conclude that there was a decrease in the employment levels of domestic workers; however, no consensus has been reached on the reasons for this. Hertz (2004) did not find evidence on a macro-level that the minimum wage legislation was the main contributing factor. Bothma and Jordaan (1998), as well as Bothma and Campher (2003), indicated that minimum wages could aggravate the situation. These two studies provided important groundwork for a third quantitative microstudy in the same suburb.

\section{Research objectives}

The above-mentioned studies were performed either prior to, or just after, the implementation of the minimum wage legislation for domestic workers. Their conclusions and predictions now need to be evaluated, five years after implementation. A survey was conducted in the same area of Bloemfontein where the previous studies of Bothma and Jordaan (1998) and Bothma and Campher (2003) had been conducted. The purpose of this article is to investigate possible structural changes in this labour market over the last decade that warrant attention from policy makers, as well as the possible employment effects of the latest minimum wage provisions that were announced by the Department of Labour at the time of the study (Department of Labour, 2006a, pp. 1-2).

\section{Research approach}

Bothma and Campher (2003, p. 194) postulated that conducting structured interviews with employers in various residential areas could provide a reliable and simple way of establishing potential job losses among domestic workers as a result of an increase in the level of minimum wages. This premise formed the basis of their 2001 survey of Langenhoven Park in Bloemfontein. Bothma and Jordaan (1998) used the same methodology in their 1997 study. A similar approach was followed in this study. A survey that consisted of structured interviews with employers of domestic servants was followed, in order to obtain the necessary data. 


\begin{abstract}
Research method Research participants

Langenhoven Park, a traditionally White suburb, is fairly young and fast-growing. It can be regarded as a middle-income area with a balanced mix of free-standing houses and townhouses, a characteristic of many urban suburbs (Van den Berg, 2001, p. 4). The Labour Force Surveys of Statistics South Africa do not focus on the type of dwelling where domestic workers are employed. This is therefore one of the areas where a microstudy of this nature adds value to the information obtained in a macrostudy. Not all households employ domestic workers, but given the increase in the number of households since 1996, it was determined that at least a 130 respondents were necessary in order to make reliable inferences. This represented approximately five per cent of the number of households in the suburb in terms of the available information at the time. This figure further corresponds with the sample sizes employed in the previous two microstudies in the same suburb, rendering the results of the studies comparable.
\end{abstract}

\section{Measuring instrument}

The questionnaire designed by Van den Berg (2001) for the 2001 survey was used as the basis for the 2006 survey of the same area. This questionnaire consisted of two sections. The first part of the questionnaire focused on a demographic profile of the domestic workers in the area. Questions referring to age, education and the number of dependants were included in this section. Additionally, they had to state their tasks, as well as the number of people they worked for, because, as Bothma and Campher (2003, p. 196) pointed out, many worked for more than one employer.

In the second section of the questionnaire, employers were interviewed with regard to the size of their households, how many days per week they employed their domestic workers, for how many hours per day the workers were employed and whether a service contract had been drawn up. To establish the level of remuneration, employers had to state whether their workers were paid on a weekly or monthly basis, how much they were paid in cash and if they were provided money for transport.

\section{Research procedure}

The research procedure echoed the one that was used by Van den Berg (2001). Langenhoven Park was divided into five geographical blocks that would ensure a more or less equal distribution of areas with houses and townhouses present in them. Within these blocks, houses and townhouses were randomly selected for possible interviews. In cases where the occupants of a selected house or townhouse did not employ a domestic worker, the adjacent dwelling was approached. The interviews were conducted at the home of the employers. The authors acted as fieldworkers and thus ensured the best possible quality control in the collection of the data. Each interview lasted approximately half an hour. The data were collected between September and November 2006, before the implementation of the latest round of wage increases in that year (Department of Labour, 2006a, pp. 1-2). In total, 132 (two more than the required minimum of 130) valid questionnaires were completed, accounting for 67 houses and 65 townhouses.

\section{Statistical analysis}

The descriptive results were compiled and compared with previous trends. Regression analysis was used to further decompose the structural relationships present in the data. The results are presented in the following section.

\section{RESULTS}

\section{Demographic features of domestic workers and their employers}

\section{Domestic workers}

The average age of the 132 domestic workers involved in this study was 43.3. This represented a marked increase from the average age of 39.2 (Bothma \& Jordaan, 1998, p. 487) in 1997 and was marginally higher than the 42.6 recorded in the 2001 survey of Bothma and Campher (2003, p. 197). These figures suggested that domestic work as an employment opportunity is continuously becoming a profession of older women. Various explanations can be offered for this trend. Given the fact that school attendance is compulsory, young people are often overqualified for domestic work and therefore may not want to take it up. The relatively low income levels and job uncertainty further discourage them from entering this job market. In addition, it can be argued that as a result of the limited employment opportunities, 'incumbents' hold on to their positions for much longer. This tendency is further encouraged by employers, who may feel that the older generation of domestic workers is more reliable.

The number of dependants remained fairly constant over the past 10 years. In 1997 and 2001 respectively, each domestic worker had an average of 2.9 and 2.5 dependants to support (Bothma \& Jordaan, 1998, p. 487; Bothma \& Campher, 2003, p. 197). In this study each domestic worker had an average of 2.39 children who depended on their income. The conclusion reached in previous studies, namely that any retrenchments in this occupation would influence a significant number of people, had therefore remained unchanged over the last decade.

The educational levels of domestic workers showed marginal improvements in the last 10 years. In 1997 and 2001, around a quarter of the domestic workers in Langenhoven Park indicated that they had not received any formal schooling (Bothma \& Jordaan, 1998, p. 487; Bothma \& Campher, 2003, pp. 197-198). The corresponding figure in the 2006 survey was 19.7 per cent. In the 2006 survey, 71 (53.8\%) of the respondents indicated that they had attended high school, as opposed to the 2001 survey when only 32.7 per cent of the respondents indicated that they had received secondary schooling (Bothma \& Campher, 2003, p. 198). This can perhaps be ascribed, in part, to the effect of the government's adult basic education initiatives.

\section{Employers}

Of the 132 employers interviewed, in the 2006 study, 67 (50.76\%) lived in free-standing houses and the rest $(49.24 \%)$ lived in townhouses. This is roughly the same as the results of the 2001 survey by Bothma and Campher (2003, p. 198), when the figures were 52.7 per cent for houses and 47.3 per cent for townhouses respectively. Table 1 presents the average occupancy in the dwellings serviced by domestic workers in Langenhoven Park, Bloemfontein from 1997 to 2006.

The number of occupants in these two types of dwellings has remained virtually constant since 1997 . Any changes in wages therefore cannot reasonably be ascribed to a possible increase in the number of people that are served by domestic workers. These and other aspects regarding the terms of employment are explained in the following section.

\section{Terms of employment}

\section{Hiring patterns}

The vast majority of employers (54, representing 41\%) indicated that they hire a domestic worker once a week, $26(19.7 \%)$ indicated they would hire one for two days, 13 $(9.8 \%)$ for three days and $35(26.5 \%)$ for four or more days. The number of employers who hire a domestic worker once a week has shown a substantial increase since 1997. The corresponding figure then was 29.4 per cent and in 2001

TABLE 1

Average occupancy in dwellings serviced by domestic workers in Langenhoven Park, Bloemfontein, South Africa, 1997-2006

\begin{tabular}{lcc}
\hline & Houses & Townhouses \\
\hline $\mathbf{1 9 9 7}$ & 3,5 & 2,1 \\
$\mathbf{2 0 0 1}$ & 3,6 & 2,2 \\
$\mathbf{2 0 0 6}$ & 3,4 & 2,1 \\
\hline
\end{tabular}


it was 33.6 per cent (Bothma \& Jordaan, 1998, p. 488; Bothma \& Campher, 2003, p. 198). This suggests that the increased regulation in this sector could be an important factor contributing to this trend, as was stated by Bothma and Jordaan (1998).

Employers who live in townhouses seem to prefer to hire parttime domestic workers; whereas, in most cases, their counterparts in houses hire their workers on a full-time basis. The fact that in 2006, 33 of the employers living in houses (49.3\%) hired their domestic workers for four days or more per week is evidence of this trend. The corresponding figure for employers living in townhouses is only three per cent.

Part-time domestic workers may be employed by more than one employer in a week. Figure 1 illustrates the changes in the number of employers for whom domestic workers in Langenhoven Park have worked since 1997.

Of the 132 domestic workers, $46(34.9 \%)$ worked for one employer, 38 (28.7\%) for two, $24(18.2 \%)$ for three, and the same number worked for four or more employers. These figures differ marginally from those gathered in the 2001 survey conducted by Bothma and Campher (2003). At that time, 36.1 per cent worked for one employer, 24.5 per cent for two, 19.1 per cent for three and 20.3 per cent for four or more (Bothma \& Campher, 2003, p. 198). The fact that the number who worked for three or four and more employers showed a slight decrease after initially increasing may indicate that working for more than two employers might not be sustainable for domestic workers over the longer term.

However, between 1997 and 2001 there were a number of wholesale changes in terms of this aspect. In 1997, as many as 67.7 per cent of the domestic workers who were interviewed at that time were employed by one household. This represents a decrease of no less than 47 per cent in five years. In terms of the other categories, the figures for 1997 were as follows: 17 per cent worked for two households, 8.5 per cent for three, and only 6.8 per cent for four or more (Bothma \& Jordaan, 1998, p. 488). This complete turnaround was indeed a significant one, which came about before the actual regulation had been promulgated. This indicated that the employers, after hearing of the possible advent of minimum wages for domestic workers, adjusted their hiring patterns beforehand. By the time the regulation of the market for domestic workers and their minimum wages came into effect the situation had already begun to stabilise. This contradicted the

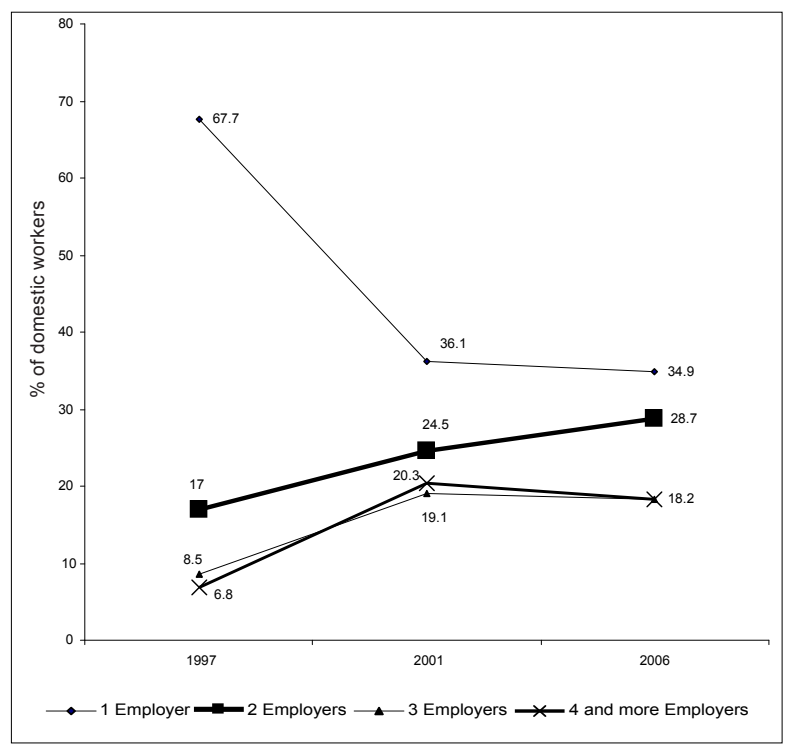

Sources: Bothma \& Jordaan, 1998, p. 488; Bothma \& Campher, 2003, p. 198; Survey dat FIGURE 1

Trends in the number of employers of domestic workers in Langenhoven Park, 1997-2006
TABLE 2

Domestic workers' task composition in Langenhoven Park, Bloemfontein, South Africa, 2001-2006

\begin{tabular}{lccccc}
\hline & Cleaning & Ironing & Washing & Cooking & Childcare \\
\hline 2001 Percentage & $99 \%$ & $94 \%$ & $65 \%$ & $21 \%$ & $8 \%$ \\
2006 Percentage & $100 \%$ & $84 \%$ & $62 \%$ & $15 \%$ & $14 \%$ \\
\hline
\end{tabular}

Sources: Bothma \& Campher, 2003, p. 198; Survey data

earlier view of Bothma and Jordaan (1998) that minimum wages in this sector will have a more profound effect in the long run.

The data also showed that a number of domestic workers were trying to increase their income by taking up more than one parttime position in the wake of a limited and shrinking number of full-time positions available to them. Yet this did not have a significant impact on the non-wage terms of employment, such as the working hours and tasks expected of domestic workers.

\section{Working hours}

The average number of working hours in Langenhoven Park has remained roughly the same over the last 10 years. In 2001, the average number of working hours per day was 6.9 (Bothma \& Campher, 2003, p. 198) compared to the average of 6.65 hours in 2006. The data further revealed that, in 2006, domestic workers in townhouses worked an average of 6.12 hours per day and those in houses 7.16 hours per day. The same consistency was evident in the combination of tasks performed in Langenhoven Park over the last 10 years.

\section{Tasks performed by domestic workers}

The various tasks of domestic workers are summarised in Table 2 . The most common task in which these workers engage was cleaning. Ironing then followed cleaning as the second most common task, which, in turn, was followed by washing. Cooking and childcare were less prevalent tasks. It was interesting to note that the percentage of domestic workers that perform childcare duties had almost doubled in the last five years. This was probably an indication that more mothers have entered into employment in the last five years.

Although many of the above-mentioned aspects of the nonwage terms of employment of domestic workers remained virtually the same, one of features that had undergone a radical change over the last decade was the existence of a written service contract between employer and domestic worker.

\section{Service contract}

Figure 2 tracks the changes in the percentage of domestic workers with a written service contract in Langenhoven Park from 1997 to 2006. Bothma and Jordaan (1998) found that in 1997 only 17.5 per cent of employers indicated that they had entered into a written service contract with their domestic worker. By 2001, this figure had almost doubled to 30.3 per cent (Bothma \& Campher, 2003 , p. 199). The situation has since continued to improve. In 2006 , only $32(24.2 \%)$ of the employers who hired a domestic worker for more than 24 hours per month had not entered into a formal service contract with their workers. These figures for Langenhoven Park over the last 10 years were consistently higher than for the rest of South Africa (Hertz, 2004). The trend corresponded with the finding of Hertz (2004) that employers' compliance in terms of the regulations had been accelerating since the date of implementation. Almost the same percentage $(22 \%)$ of employers who had a domestic worker in their service for more than 24 hours per month did not register them with the Unemployment Insurance Fund (UIF) as is required by the Department of Labour (Department of Labour, 2006b, p. 1).

\section{Wages}

Table 3 provides the average daily wage of domestic workers per category of number of days employed. Domestic workers in houses earned more than their counterparts in townhouses. 


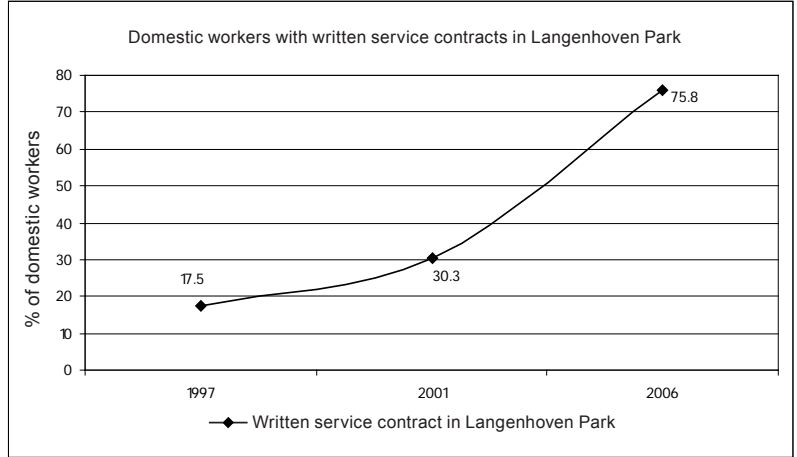

Sources: Bothma \& Jordaan, 1998, p. 488; Bothma \& Campher, 2003, p. 199; Survey data FIGURE 2

Domestic workers with written service contract in Langenhoven Park, 1997-2006

TABLE 3

The average daily wage of domestic workers per category of number of days employed in Langenhoven Park, Bloemfontein, South Africa, 2006

\begin{tabular}{lccrr}
\hline & One day & Two days & Three days & Full-time \\
\hline Houses & $\mathrm{R} 71.90$ & $\mathrm{R} 68.26$ & $\mathrm{R} 62.82$ & $\mathrm{R} 48.08$ \\
Townhouses & $\mathrm{R} 63.64$ & $\mathrm{R} 61.01$ & $\mathrm{R} 57.00$ & $\mathrm{R} 46.39$ \\
All dwellings & $\mathrm{R} 65.47$ & $\mathrm{R} 63.52$ & $\mathrm{R} 62.37$ & $\mathrm{R} 47.99$ \\
\hline Source: Survey data & & & &
\end{tabular}

Source: Survey data

\section{TABLE 4}

Changes in the average daily wage of domestic workers per category of number of days employed in Langenhoven Park, Bloemfontein, South Africa, 2001-2006

\begin{tabular}{lcccc}
\hline & 2001 & 2006 & Change & $\begin{array}{c}\text { Average change } \\
\text { p.a. }\end{array}$ \\
\hline 1 day & R45.68 & R65.47 & $43.30 \%$ & $8.70 \%$ \\
2 days & R40.79 & R63.52 & $55.70 \%$ & $11.10 \%$ \\
3 days & $\mathrm{R} 37.01$ & $\mathrm{R} 62.37$ & $68.50 \%$ & $13.70 \%$ \\
Full-time & $\mathrm{R} 30.16$ & $\mathrm{R} 47.99$ & $59.10 \%$ & $11.80 \%$ \\
All categories & $\mathrm{R} 39.02$ & $\mathrm{R} 61.31$ & $57.10 \%$ & $11.40 \%$ \\
\hline
\end{tabular}

Sources: Bothma \& Campher, 2003, p. 199; Survey data

The income differentials of the employers as well as the scope of the tasks to be performed may explain this trend. The workload in a house seems to be higher than in a smaller townhouse, as houses have more occupants on average and therefore domestic workers generally work longer hours there. This feature of Langenhoven Park remained largely unchanged and the support given by Bothma and Campher (2003, p. 204) to Cosatu's 2001 proposal that minimum wages in this sector must be set not according to geographical differences but according to the work carried out, may still be in order.

The wages also varied according to the number of days worked for an employer per week. The highest daily wage was earned by those who were employed by a specific employer for one day per week. The average wage decreased as the number of days increased. This trend was also evident in 2001 (Bothma \& Campher, 2003).

Table 4 provides the details of changes in the nominal wages of domestic workers since 2001 in Langenhoven Park, Bloemfontein. This table shows that the annual increases in the daily cash wages were far higher than the average rate of inflation for the same period. The average annual increase in the consumer price index (CPI) for South Africa from 2001 to 2006 was 4.9 per cent (Statistics South Africa, 2006b, p. 1). This implied that the wages did not merely increase in nominal terms but in real terms as well, which corresponded with the findings of Hertz (2004) for the whole country and is a continuation of a trend that had become apparent since 1997.
The average daily cash wage, in all categories, increased by 37.3 per cent between 1997 and 2001. This represented an average increase of 8.3 per cent per annum, in comparison with an average increase in the CPI of 5.6 per cent per annum for the same period (Bothma \& Campher, 2003, p. 201).

The average hourly cash wage of all domestic servants was R9.73. The corresponding amount in 2001 was R6.19. This was a marked increase of 57.19 per cent over the period in question. Like the average daily wages, average hourly wages also displayed a negative correlation with the number of days worked for a specific employer.

Only eight $(6 \%)$ of the employers involved in this survey were paying their domestic workers less than the minimum wage of 2006 as prescribed by the Department of Labour. In 2001, 7.9 per cent of the employers were paying an hourly wage less than the minimum wage at the time of R3.07 per hour. All those employees hired their domestic workers on a full-time basis at the time (Bothma \& Campher, 2003, p. 200).

In order to supplement the comparisons described above, the data obtained in the 2006 survey of domestic workers in Langenhoven Park were used in a cross-section regression analysis to investigate the determining factors of the hourly and daily wages of domestic workers. This showed that other structural factors, apart from minimum wages, were also influencing the wage levels of domestic workers. The results of this analysis are presented below.

\section{Regression analysis}

A number of variables were considered for the Langenhoven Park analysis. These are summarised in Table 5.

Cross-sectional regressions were run for both wages per hour and wages per day as dependent variables. The results were analysed and the variables used in the regression analysis reduced accordingly. The variables for age and the number of occupants were excluded as they consistently yielded results that were not statistically significant. The regression was tested for heteroscedasticity with the White test. The regression with the daily wage as dependent variable did not display any heteroscedasticity. In the case of the hourly wage as a dependent variable, heteroscedasticity was present and was subsequently eliminated by estimating White heteroscedasticity-consistent standard errors and covariance. The final estimates are summarised in Table 6.

The level of schooling seemed to have some positive influence on the level of wages but was not statistically significant at 10 per cent or lower. The coefficients for the variable of working hours were positive and negative for daily and hourly wages respectively as expected, but these were only marginally significant

There was, however, a statistically significant negative relationship between both the hourly and the daily cash wage and the number of days worked at the home of any one employer. In practice, this implied that as domestic workers were working for fewer days per week at an individual employer, they earned higher wages. The econometric evidence supported the observed structural changes in the hiring patterns of domestic workers. This warranted a question regarding the possible employment effects of the latest increases in the minimum wage of domestic workers in this area, an aspect which is addressed in the next section.

\section{Possible employment effects of 2007 minimum wage levels}

The new level of minimum wages for domestic workers applicable to Langenhoven Park was set at R5.47 per hour for workers working more than 27 ordinary hours per week and R6.46 for those working 27 hours or less. This became applicable from 1 December 2006 to 30 November 2007 (Department of Labour, 2006a, p. 1). 
TABLE 5

Variables used in the Langenhoven Park regression analysis

\begin{tabular}{ll}
\hline Wage per hour & The cash wage per hour of domestic workers \\
Wage per day & The daily cash wage of domestic workers \\
Days per week & $\begin{array}{l}\text { The number of days per week a domestic worker is } \\
\text { employed by the employers who were interviewed } \\
\text { Dummy variable with a value of } 1 \text { for a townhouse and } 0 \text { for } \\
\text { free-standing houses }\end{array}$ \\
School & $\begin{array}{l}\text { The level of completed schooling of domestic workers } \\
\text { Hours }\end{array}$ \\
Occupants & $\begin{array}{l}\text { The number of hours worked per day by day labourers } \\
\text { Themestic worker is employed }\end{array}$ \\
Age & Age of the domestic worker
\end{tabular}

TABLE 6

Cross-sectional regression results: Hourly and daily wage of domestic workers

\begin{tabular}{lll}
\hline & Wage per hour & Wage per day \\
\hline C & 20.2123 & 64.36101 \\
& $(13.92725)^{\star \star}$ & $(7.793404)^{\star \star}$
\end{tabular}

$-0.632983$

$(-3.567230)^{* *}$

$-5.405042$

$(-4.661261)^{\star \star}$

Dumth

$-0.660167$

$(-1.122474)$

$-7.485386$

$(-2.050459)^{\star}$

School

0.112801

0.421263

$-0.958078$

Hours

$-1.387194$

$(-6.202610)^{\star *}$

1.74221

$-1.526113$

132

Observations

Adjusted R-squared $\quad 0.449886$

0.123584

In order to assess the possible job losses that resulted from these new wage requirements, it was necessary to compare current wage levels with the prescribed minima for 2007. The data showed that only $13(9.84 \%)$ of the 132 employers were currently paying wages that were lower than the prescribed R5.47 for workers working more than 27 ordinary hours per week in 2007. When the higher level of R6.46 for those working 27 ordinary hours or less was considered, the figure doubled to 26 (17.4\%).

These employers had three options: they could pay the new minimum wage, discharge their workers, or reduce the working hours of their domestic workers by hiring a domestic worker on a part-time basis, thereby reducing the monthly expenditure on this service. The last option seemed to be the most likely one. The continued increase in the number of domestic workers who worked for more than one employer seemed to support this view. This had the potential to simultaneously increase the demand for part-time domestic workers and to reduce the demand for full-time domestic workers. This structural change indicated that regulating this labour market remained a complex and delicate task in spite of the evidence, suggesting that employers had discounted the initial effect of the advent of minimum wages for domestic workers.

\section{DISCUSSION}

The above comparisons show that a number of the trends identified by previous studies are still evident. There were minor changes in the level of education attained by domestic workers in Langenhoven Park and the workers are, on average, gradually becoming older. The number of dependants of domestic workers over the last 10 years remained steady. The same consistency is evident in the number of occupants living in the households where domestic workers are employed. Certain

non-wage terms of employment have also remained virtually the same over the last decade. These include the working hours and the tasks performed by domestic workers. However, the existence of written service contracts with domestic workers showed a significant increase over the same period. The biggest changes in this labour market came in terms of the wages earned and the shift from full-time to part-time work.

The most significant decrease in the number of full-time domestic workers was from 1997 to 2001. The 2006 survey showed that this trend has started to stabilise since then. This indicates that employers adjusted their hiring patterns well in advance of the advent of minimum wages. Nominal and real wages have increased significantly during the last 10 years and have shown a negative relationship with the number of days worked for a particular employer. Research has shown that the real wages of domestic workers have increased as a result of the implementation of minimum wage legislation in this sector. Evidence exists that the non-wage terms of employment have also improved with the vast majority of domestic workers who now enjoy the benefit of a written service contract. Many of the trends observed in previous studies have not shown any real changes in the last decade. The educational levels, hours worked, tasks performed and the number of dependants of domestic workers remained fairly stable. The average age of domestic workers in Langenhoven Park is slowly increasing, with an increase in average age of four years over the last decade.

There have been some important structural changes over the last decade as well. It is of great importance that domestic work is increasingly becoming a part-time profession. The percentage of workers who worked for a single employer decreased sharply by 46.7 per cent between 1997 and 2001 before it started to stabilise. The greatest change was in the five years before the advent of the minimum wage legislation. The employers of domestic workers adjusted their hiring patterns in anticipation of this. By the time the regulation of the market for domestic workers and their minimum wages came into effect, this adjustment was in place. This contradicts the earlier prediction of Bothma and Jordaan (1998) that minimum wages in this sector will have a greater long-term impact. The cross-sectional regression analysis confirms the important role played by the number of days worked per week for any one employer in explaining the level of hourly and daily wages in Langenhoven Park in 2006.

It is encouraging to see that employers are continuing to comply with the provisions of the Department of Labour with regard to written service contract and the UIF registration of their domestic workers. From 1997 to 2006, the percentage of employers who had service contracts with their domestic workers increased by 333 per cent. The number of employers who registered their domestic workers for UIF deductions also increased noticeably over the same period.

The comparison of the results of three microstudies in the same suburb makes a unique contribution to the existing research. It tracks the structural changes in the labour market for domestic workers both before and after the promulgation of minimum wage legislation. These results highlight the behavioural changes of employers of domestic workers in the wake of minimum wage legislation. It supplements the inferences that can be made from using national statistics from the various labour force surveys of Statistics South Africa.

\section{Conclusion}

These structural changes rendered the labour market for domestic workers complex and dynamic, a situation that could complicate the setting of appropriate levels of minimum wages for workers in this industry. The intention of the Minister of Labour over the last 10 years to lay down lower minima for fulltime domestic workers than for part-timers has definite merit. All three surveys conducted in Langenhoven Park during the 
last decade showed that part-time domestic workers did indeed earn higher wages than their full-time counterparts. This was in line with the recommendation of Bothma and Jordaan (1998) that minimum wages for domestic workers should be regressive, with higher wages for part-time than for full-time workers.

The wage increase of CPIX plus two per cent prescribed by the minister IN November 2006 seemed quite reasonable. The CPI for 2006 was on average only 4.7 per cent (Statistics South Africa, 2006b, p. 1). The lowest average annual increase (8.7\%) granted by employers in Langenhoven Park between 2001 and 2006 was for workers who worked only one day per week. All other categories yielded higher increases. The effect of the latest wage increase will probably be seen in a continued increase in the number of part-time domestic workers.

A limiting factor in the analysis was the unavailability of successive waves of data from the same respondents. This would have enabled researchers to conduct panel data analysis to further investigate these aspects.

The minister's task of balancing the improvement of the lives of domestic workers and the possible adverse consequences of the legislation, in the form of job losses, remains as daunting as it was ten years ago. Further microstudies like these can contribute to an improved understanding of the impact of these policies on the lives of those who are the intended beneficiaries.

\section{ACKNOWLEDGEMENTS}

A previous version of this paper was presented at the Scottish Economic Society Conference, 2-4 April 2007 in Perth, Scotland. The authors wish to thank Ms Anmar Pretorius, Mr Krige Siebrits, Prof. Ronald Mears, and an anonymous referee for valuable comments on earlier drafts. The usual disclaimer applies.

\section{REFERENCES}

Bothma, L.J., \& Jordaan, C.J. (1998). 'n Minimum loon vir huishulpe: Antwoorde vir beleidmakers. South African Journal of Economic and Management Sciences, 1(3), 483-497.

Bothma, L.J., \& Campher, C. (2003). Minimum wages for domestic workers: A comprehensive analysis. Acta Academica, 35(1), 190-205.
Cosatu (2001). Submission on the domestic workers sectoral determination report. Retrieved March 17, 2006, from http://www.cosatu.org.za/docs/2001/Domestic.htm\#set

Davidson, S., \& Grossett, M. (1995). The economic consequences of legislation governing working conditions of domestic workers. South African Journal of Economic and Management Sciences, 15 (autumn), 91-103.

Department of Labour. (1996). Restructuring the South African labour market. Pretoria: Government Printer.

Department of Labour. (2002). Sectoral determination 7: Domestic worker sector. Pretoria: Government Printer.

Department of Labour. (2006a). Wage tables for the domestic worker sector. Retrieved April 26, 2007, from http://www.labour.gov.za/download/11485/ Useful\%20Document $\% 20 \% 20$ Domestic\%20Worker\%20 Wage\%20increase \%202006.doc

Department of Labour. (2006b). Amendment Unemployment Insurance (UIF) Act. Retrieved March 28, 2007, from http:// www.labour.gov.za/legislation/ amendments.jsp?legislatio $\mathrm{nId}=5621 \&$ actId $=7932 \&$ doc $\_$id $=8485$

Hertz, T. (2004). Have minimum wages benefited South Africa's domestic service workers? Forum on African development and poverty reduction: The macro-micro linkage, 13-15 October 2004, Somerset West, South Africa: Lord Charles Hotel.

Statistics South Africa. (2006a). Labour Force Survey, March 2006. Pretoria: Government Printer.

Statistics South Africa. (2006b). Annual inflation on a monthly basis, Consumer Price Index (P0141.1). Retrieved February 20, 2007, from http://www.statssa.gov.za/keyindicators/CPI/ CPIHistory.pdf

Van den Berg, E. (2001). Huiswerkers en die vasstelling van minimum lone: ' $n$ Vergelykende perspektief. Unpublished honours

mini-dissertation, Department of Economics, University of the Free State, Bloemfontein, South Africa.

Wilson, G.L. (2006). One of 850000 domestic workers. Retrieved March 20, 2008, from http://www.mywage.co.za/main/ Sfricaworks/domesticworker 